Acta vet. scand. $1970,11,209-218$.

From the National Veterinary Institute, Stockholm, Sweden.

\title{
THE DISAPPEARANCE RATE IN REINDEER OF FAMPHUR AN ORGANOPHOSPHORUS PARASITICIDE
}

\author{
By \\ Kurt Erne and Magnus Nordkvist
}

The Swedish reindeer stock numbers about 250,000 animals. Approximately $95 \%$ of these are estimated to be infested, to a higher or lower degree, with the reindeer warble fly (Oedemagena tarandi L.) and the reindeer nostril fly (Cephenomyia trompe L.). The losses to the reindeer industry caused by these 2 parasites may be estimated as $1.5-2.0$ million kronor annually, or about $15 \%$ of the total yield.

During the period 1958-1966 several systemic parasiticides were tested against the larvae of Oedemagena (Nordkvist 1967). The most promising results were obtained with Warbex (Famophos), and this preparation was selected for further studies. The active ingredient is famphur or 0,0 -dimethyl-0,p-( $N, N$-dimethylsulphamoyl) phenyl phosphorothioate. If the preliminary results will be confirmed, it is planned to use this preparation in an extensive field trial and then in a full scale control campaign.

From a food hygienic point of view it is essential to know the fate of any chemical applied to animals involved in food production. According to studies reported by Zacherl et al. (1965), Gatterdam et al. (1967) and Pasarela et al. (1967) famphur is rather rapidly metabolized and excreted in cattle. Of the metabolites of famphur only the oxygen analogue, famoxon, seems to be distinctly toxic to mammals. Apparantly, there is no published information on the fate of famphur in the reindeer.

The present experiments were performed in order to elucidate the disappearance rates of famphur and famoxon from blood and tissues of reindeer treated intramuscularly with famphur. 


\section{MATERIAL}

Warbex injectable solution, American Cyanamide Co., containing $35 \%(\mathrm{w} / \mathrm{v})$ of famphur.

Data regarding the reindeer used in these experiments are summarized in Table 1.

T a b l e 1. Sex, age and weight data of reindeer used in famphur experiments.

\begin{tabular}{|c|c|c|c|c|}
\hline $\begin{array}{c}\text { Animal } \\
\text { no. }\end{array}$ & Sex & $\begin{array}{c}\text { Age } \\
\text { years }\end{array}$ & $\begin{array}{c}\text { Body weight } \\
\text { at treatment } \\
\mathbf{k g}\end{array}$ & Remarks \\
\hline \multicolumn{5}{|l|}{ Expt. A } \\
\hline 533 & $0^{x}$ & 2 & 85 & \\
\hline 634 & $\sigma^{x}$ & 1 & 68 & \\
\hline \multicolumn{5}{|l|}{ Expt. B } \\
\hline 533 & 0 & 3 & 96 & $\cdot$ \\
\hline 119 & 우 & 7 & 80 & pregnant (2nd m.) \\
\hline \multicolumn{5}{|l|}{ Expt. C } \\
\hline 122 & $\sigma^{x}$ & 0.3 & 27 & \\
\hline 143 & $\sigma^{x}$ & 0.3 & 33 & \\
\hline \multicolumn{5}{|l|}{ Expt. D } \\
\hline 326 & $\theta$ & 5 & 120 & \\
\hline 432 & 0 & 4 & 110 & \\
\hline 533 & 0 & 3 & 116 & \\
\hline O 3835 & 우 & - & 65 & $\begin{array}{l}\text { free-living, killed in traffic } \\
\text { accident } 2 \text { days after dosing }\end{array}$ \\
\hline
\end{tabular}

$\theta=$ castrated.

\section{Cholinesterase activity (Experiment A)}

Two male reindeer bred at this institute were given a single intramuscular dose (in the thigh muscle) of Warbex $35 \%$ equivalent to $20 \mathrm{mg} / \mathrm{kg}$ body weight of famphur. Blood samples were withdrawn from a jugular vein at intervals from 1 week before to 4 weeks after the treatment.

The samples were immediately centrifuged at 2,000 r.p.m. for 20 min., plasma was separated and red corpuscles were washed 3 times with physiological saline and then haemolyzed with water to give a final volume equal to that of the original blood sample.

Plasma and erythrocyte cholinesterase activities were measured micromanometrically according to Augustinsson (1957) *).

*) For these determinations we are indebted to Assistant Professor K.-E. Augustinsson, Institute of Biochemistry, Stockholm. 
Elimination studies (Experiments $B, C$ and $D$ )

Three series of experiments involving juvenile as well as adult reindeer were performed.

Experiment $B$. Two adult reindeer, 1 male and 1 pregnant female, were injected intramuscularly (in the thigh) with a single dose of Warbex equivalent to $30 \mathrm{mg} / \mathrm{kg}$ body weight of famphur. Blood samples were withdrawn from a jugular vein before and 1, 8, 16, 22 and 29 days after dosing.

Plasma was immediately separated by centrifugation, and erythrocytes were washed with saline and haemolyzed as described above. Samples were stored at $-20^{\circ} \mathrm{C}$ awaiting analysis for famphur and famoxon.

Experiment $C$. Two reindeer calves were treated with Warbex as in the preceding experiment. Blood samples were drawn at $5,11,26,33,54,72$ and 108 hrs. post-treatment, and plasma was separated.

Both animals were sacrificed at 4.5 days ( $108 \mathrm{hrs}$.) and tissue samples taken to analysis for famphur and famoxon from liver, kidneys, thigh (injection site) and shoulder muscle. The samples were kept at $-20^{\circ} \mathrm{C}$ awaiting analysis.

Experiment $D$. Three adult castrated reindeer males were treated with Warbex as in Experiments $A$ and $B$, and blood samples drawn at 5, 8, 24, 31, 54, 72, 96, 120 and 144 hrs. posttreatment, and plasma was separated.

One animal was sacrificed at 6 days (144 hrs.), 1 at 12 and 1 at 20 days post-treatment, and tissue samples taken to analysis.

Included in this experiment was also 1 free-living animal dosed with Warbex at the same level and accidentally killed by a car 2 days after treatment.

\section{Determination of famphur and famoxon}

Famphur and famoxon were determined in blood and tissue samples by a technique largely based on the method of Pasarela et al. (1967).

Plasma and haemolyzed erythrocytes were extracted with acetone in the presence of phosphoric acid, and after evaporation of the solvent the residue was partitioned between acetonitrile and hexane, and the acetonitrile soluble partitioned between saturated aqueous sodium chloride and methylene chloride. The solvent extract was chromatographed on an alumina column, 
and famphur and famoxon were separately eluted with methylene chloride and $20 \%$ methanol in methylene chloride, respectively, and hydrolyzed to give (in both instances) p-dimethylsulphamoylphenol. The phenol was separated and determined by thinlayer chromatography on fluorescent silica gel using methanolmethylene chloride-ammonia (20:80:2, by volume) as the developing solvent. The phenol was detected by means of ultraviolet absorption and by diazo coupling (with fast blue $B$ salt) and determined by dilution to the u.v. detection limit (ca. $0.03 \mu \mathrm{g}$ ). At intervals, the determination was checked by gas chromatography of the trimethylsilylated phenol.

Tissue samples were extracted by homogenizing with $80 \%$ aqueous acetonitrile. The solvent was evaporated, the residue partitioned between saturated sodium chloride and methylene chloride, and then the procedure for plasma was followed.

In control experiments, famphur added to plasma or liver at the 2-p.p.m. level was recovered to about $70-90 \%$, with a standard deviation of approximately $10 \%$.

\section{RESULTS}

\section{Cholinesterase activity}

In Experiment A profuse diarrhoea developed in both animals within 1 week after dosing. On the 4th day of diarrhoea the animals were given $\mathrm{E}$. coli-serum $(50 \mathrm{ml}$ subcutaneously) and after that slowly recovered.

The results of the cholinesterase determinations are summarized in Table 2. It is apparent that both the plasma and erytrocyte cholinesterase activities became inhibited to about $50 \%$. The plasma activity dropped rapidly within 1 day after dosing and returned to normal (or nearly so) in 3-4 weeks, whereas the erythrocyte activity declined more gradually and remained low throughout the observation period.

\section{Elimination studies}

The famphur and famoxon levels found in plasma of the reindeer at different times after dosing are shown in Tables 3-5.

As seen from Table 3 (Experiment B), measurable levels of famphur and famoxon were detected in plasma and in erythrocytes only at the first day after dosing. The erythrocyte levels 
T a b l e 2. Cholinesterase activities in plasma and erythrocytes of reindeer given famphur, $20 \mathrm{mg} / \mathrm{kg}$ body weight, as a single intramuscular dose (Experiment A).

\begin{tabular}{cccccc}
\hline $\begin{array}{c}\text { Days pre- } \\
\text { or post- } \\
\text { treatment }\end{array}$ & \multicolumn{2}{c}{ No. 533 } & & \multicolumn{2}{c}{ No. 634 } \\
\cline { 2 - 3 } \cline { 5 - 6 } & plasma $^{1}$ ) & erythrocytes $\left.^{2}\right)$ & & plasma & \\
\hline-7 & 56 & 75 & & erythrocytes $^{2}$ ) \\
\hline-2 & 52 & 70 & & 74 & 70 \\
0 & 55 & 86 & 68 & 62 \\
$\left.0^{3}\right)$ & 43 & 73 & 73 & 80 \\
$\left.1^{4}\right)$ & 23 & 46 & 31 & 63 \\
8 & 26 & 38 & 18 & 49 \\
12 & 31 & 30 & 36 & 54 \\
15 & 27 & 36 & 42 & 42 \\
22 & 42 & 33 & 53 & 43 \\
28 & 45 & 39 & 64 & 43 \\
\hline
\end{tabular}

1) $\mu \mathrm{l} \mathrm{CO}_{2} / 0.4 \mathrm{ml}$.

2) $\mu \mathrm{l} \mathrm{CO} / 0.1 \mathrm{ml}$.

3) $1 \mathrm{hr}$. post-treatment.

4) 24 hrs. post-treatment.

of famphur amounted to less than $5 \%$ of the corresponding plasma levels, famoxon being barely detectable in the blood cells.

From the experiments reported in Tables 4 and 5 appears that peak levels of plasma famphur ranging between 1 and 16 p.p.m., were attained between 5 and $\mathbf{1 5}$ hrs. Famoxon levels consistently were below 1 p.p.m., mostly amounting to only about $10 \%$ of the corresponding famphur levels in plasma.

T able 3. Famphur and famoxon levels (p.p.m.) in plasma and erythrocytes of adult reindeer at different times after a single i.m. dose of $30 \mathrm{mg} /$ $\mathrm{kg}$ b.w. of famphur (Experiment B).

\begin{tabular}{|c|c|c|c|c|c|c|c|c|}
\hline \multirow{3}{*}{$\begin{array}{c}\text { Days } \\
\text { post-treat- } \\
\text { ment }\end{array}$} & \multicolumn{4}{|c|}{ No. 533} & \multicolumn{4}{|c|}{ No. 119} \\
\hline & \multicolumn{2}{|c|}{ plasma } & \multicolumn{2}{|c|}{ erythrocytes } & \multicolumn{2}{|c|}{ plasma } & \multicolumn{2}{|c|}{ erythrocytes } \\
\hline & famphur & famoxon & famphur & famoxon & famphur & famoxon & famphur & famoxon \\
\hline 0 & n.d. $\left.{ }^{\star}\right)$ & n.d. & n.d. & n.d. & n.d. & n.d. & n.d. & n.d. \\
\hline 1 & 4 & 0.20 & 0.10 & n.d. & 5 & 0.10 & 0.20 & 0.05 \\
\hline 8 & n.d. & n.d. & n.d. & n.d. & n.d. & n.d. & n.d. & n.d. \\
\hline 16 & n.d. & n.d. & & & n.d. & n.d. & & \\
\hline 22 & n.d. & n.d. & & & n.d. & n.d. & & \\
\hline 29 & n.d. & n.d. & & & n.d. & n.d. & & \\
\hline
\end{tabular}

^) n.d.: not detectable ( $<0.02$ p.p.m.). 
T a b l e 4. Famphur and famoxon levels (p.p.m.) in plasma of young reindeer at different times after a single i.m. dose of $30 \mathrm{mg} / \mathrm{kg} \mathrm{b.w.}$ of famphur (Experiment $\mathrm{C}$ ).

\begin{tabular}{rlllll}
\hline \multirow{2}{*}{$\begin{array}{c}\text { Hours } \\
\text { post-treatment }\end{array}$} & \multicolumn{2}{c}{ No 122 } & & \multicolumn{2}{c}{ No. 143 } \\
\cline { 2 - 4 } & famphur & famoxon & & famphur & famoxon \\
\hline 5 & 0.5 & 0.08 & & 0.5 & 0.05 \\
11 & 0.7 & 0.06 & 0.6 & 0.04 \\
26 & 1.0 & n.d. & & 0.5 & n.d. \\
33 & 0.3 & n.d. & & 0.8 & n.d. \\
54 & 0.08 & & 0.1 & \\
72 & n.d. & & n.d. & \\
108 & n.d. & & n.d. & \\
\hline
\end{tabular}

$\left.{ }^{\star}\right)$ n.d. $=$ not detectable $(<0.02$ p.p.m. $)$.

T a b l e 5. Famphur and famoxon levels (p.p.m.) in plasma of adult reindeer at different times after a single i.m. dose of $30 \mathrm{mg} / \mathrm{kg} \mathrm{b.w}$. of famphur (Experiment D).

\begin{tabular}{|c|c|c|c|c|c|c|}
\hline \multirow{2}{*}{$\begin{array}{c}\text { Hours } \\
\text { post- } \\
\text { treatment }\end{array}$} & \multicolumn{2}{|c|}{ No. 326} & \multicolumn{2}{|c|}{ No. 432} & \multicolumn{2}{|c|}{ No. 533} \\
\hline & famphur & famoxon & faımphur & famoxun & famphur & famoxon \\
\hline 5 & 10 & 0.5 & 16 & 0.7 & 2.1 & 0.05 \\
\hline 8 & 1.1 & 0.6 & 5 & 0.8 & 2.5 & 0.05 \\
\hline 24 & 1.0 & 0.15 & 0.8 & 0.08 & 1.0 & 0.10 \\
\hline 31 & 0.7 & 0.10 & 0.8 & $0 . \dot{05}$ & 0.5 & 0.05 \\
\hline 54 & 0.5 & n.d. $\left.{ }^{\star}\right)$ & 0.7 & n.d. & 0.3 & n.d. \\
\hline 72 & 0.5 & & 0.03 & & - & \\
\hline 96 & n.d. & & n.d. & & n.d. & \\
\hline 120 & n.d. & & n.d. & & n.d. & \\
\hline 144 & n.d. & & n.d. & & n.d. & \\
\hline
\end{tabular}

^) n.d. $=$ not detectable $(<0.02$ p.p.m. $)$.

Table 6 shows the famphur and famoxon levels observed in selected tissues of reindeer at different times after dosing.

The observed tissue levels consistently were low, except at the injection site. Thus, in liver famphur and famoxon were detectable for 4.5 days and in kidney and shoulder muscle for 12 days. At 20 days the only residue encountered was in muscle tissue adjacent to the injection site (famoxon, 0.05 p.p.m.). In this region the residue levels of famphur were found to vary within wide limits, from 0.06 p.p.m. at 6 to 40 p.p.m. at 12 and below 0.02 p.p.m. at 20 days. Famoxon levels were mostly low. 
T a b l e 6. Tissue levels (p.p.m., fresh weight) of famphur and famoxon in adult reindeer at different times after a single i.m. dose of $30 \mathrm{mg} / \mathrm{kg} \mathrm{b.w}$. of famphur (Experiment D). Values are means of 2-4 determinations.

\begin{tabular}{|c|c|c|c|c|c|c|c|c|c|}
\hline \multirow{2}{*}{$\underset{\text { no. }}{\text { Animal }}$} & \multirow{2}{*}{$\begin{array}{c}\text { Days } \\
\text { post- } \\
\text { treatment }\end{array}$} & \multicolumn{2}{|c|}{ Liver } & \multicolumn{2}{|c|}{ Kidney } & \multicolumn{2}{|c|}{$\begin{array}{l}\text { Thigh muscle } \\
\text { (injection site) }\end{array}$} & \multicolumn{2}{|c|}{ Shoulder muscle } \\
\hline & & famphur & famoxon & famphur & famoxon & famphur & famoxon & famphur & famoxon \\
\hline 03835 & 2 & 0.15 & n.d. $\left.{ }^{\star}\right)$ & 0.30 & 0.03 & $\left.10^{\star *}\right)$ & 0.4 & - & - \\
\hline 122 & 4.5 & n.d. & n.d. & n.d. & n.d. & 1.3 & n.d. & n.d. & n.d. \\
\hline 143 & 4.5 & 0.07 & 0.02 & 0.05 & 0.07 & 0.07 & 0.02 & n.d. & n.d. \\
\hline 326 & 6 & n.d. & n.d. & 0.15 & n.d. & 0.06 & n.d. & n.d. & n.d. \\
\hline 533 & 12 & n.d. & n.d. & n.d. & 0.10 & $\left.20^{\star \star *}\right)$ & 0.05 & 0.07 & 0.10 \\
\hline 432 & 20 & n.d. & n.d. & n.d. & n.d. & n.d. & 0.05 & n.d. & n.d. \\
\hline
\end{tabular}

$\left.{ }^{\star}\right)$ n.d. $=$ not detectable $(<0.02$ p.p.m. $)$.

**) range $3-25$ p.p.m. (4 determinations).

***) range $1-40$ p.p.m. (4 determinations).

\section{DISCUSSION}

The observed inhibition of plasma and erythrocyte cholin-esterase activities indicates a definite toxic action of the organophosphate on the host animal. However, clinical signs of toxicity were not seen regularly and, when so, usually regressed spontaneously within a few days. The rather rapid decline and return to normal of plasma esterase activity are in agreement with the results for cattle reported by Zacherl et al. (1965).

The plasma concentration-versus-time-curves for famphur in reindeer were of 2 general types (Tables 4 and 5 ), either steep with distinct maxima within $8 \mathrm{hrs}$. after dosing or flat with diffuse maxima beyond $24 \mathrm{hrs}$. Although the latter type, indicating a low absorption rate was predominant in the young animals, the material is to scarce to allow an assessment of a possible age factor. Most probably absorption is largely governed by the localization of the intramuscular depot relative to the vascular system of the tissue. The disappearance rate of famphur from plasma was rather high; irrespective of the shape of the curve the plasma levels declined to below 0.02 p.p.m. in $72-96 \mathrm{hrs}$. Estimated plasma half-life values were of the order of 5-10 hrs.

Famoxon was included in the residue studies because it is the toxicologically most important metabolite (Gatterdam et al. 1967). In plasma, famoxon usually constituted only about 0.1 of the famphur content, this being in agreement with results obtained with cattle and sheep by Gatterdam et al. These workers 
also found a higher proportion of famoxon in plasma, if famphur was administered intravenously rather than intramuscular. The reason for this apparent discrepancy is unclear.

In our experiments only trace amounts of famphur were found in the erythrocytes (the levels not exceeding $5 \%$ of the corresponding plasma levels) and hardly any famoxon, thus suggesting a low accumulation rate.

In the tissues examined (liver, kidney and skeletal muscle selected on food-hygienic grounds) low residue levels were consistently found, excepting muscle tissue from the injection site. The very high levels encountered in this tissue even at 12 days post-treatment (Table 6) indicate that the absorption rate from the injected depot may be low. The injection site, therefore, should be suitably marked on treatment and the adjacent regions discarded on slaughter. Otherwise the results do not seem alarming from a food-hygienic point of view, residue levels of famphur and famoxon being detectable only for 12 days in liver, kidney and muscle remote from the injection site. These results are in agreement with the ready elimination of famphur, observed in cattle and sheep upon oral administration (Pasarela et al. 1967).

On the basis of the experimental evidence presented here, the intramuscular administration to reindeer of Warbex at a rate corresponding to $30 \mathrm{mg} / \mathrm{kg}$ body weight of famphur might be considered as reasonably safe from a consumer's point of view, provided the animals are not slaughtered before 3 weeks posttreatment and muscle from the injection site is discarded.

\section{REFERENCES}

Augustinsson, K.-B.: Assay methods for cholinesterases. Meth. biochem. Anal. 1957, 5, 1-63.

Gatterdam, P. E., L. A. Wozniak, M. W. Bullock, G. L. Parks \& J. E. Boyd: Absorption, metabolism, and excretion of tritium-labelled famphur in the sheep and calf. J. agric. Food Chem. 1967, 15, $845-853$.

Nordkvist, M.: Treatment experiments with systemic insecticides against the larvae of the reindeer grub fly (Oedemagena tarandi L.) and the reindeer nostril fly (Cephenomyia trompe L.). Nord. Vet.-Med. 1967, 19, 281-293.

Pasarela, N. R., R. E. Tondreau, W. R. Bohn \& G. O. Gale: Gas chromatographic determination of famphur and its oxygen analog residues in bovine milk, blood and edible tissues. J. agric. Food Chem. 1967, 15, 920-926. 
Zacherl, M. K., W. Stöckl, M. Weiser, G. Litschauer \& A. Zuchi: Chemische Untersuchungen nach Applikation von Warbex. (Chemical investigations after administration of Warbex). Wien. tieräztl. Mschr. 1965, 52, 669-675.

\section{SUMMARY}

The present investigations were carried out in order to study the disappearance rate in reindeer of famphur (0,0-dimethyl-0,p- $(\mathrm{N}, \mathrm{N}-\mathrm{di}$ methylsulphamoyl) phenyl phosphorothioate), a promising systemic parasiticide for the control of reindeer warble and nostril flies.

The compound was administered intramuscularly to reindeer as a single dose (in the form of the preparation Warbex). At a dose of $20 \mathrm{mg} / \mathrm{kg}$ body weight (2 animals) famphur caused inhibition of plasma and erythrocyte cholinesterase activities by about $50 \%$. The plasma esterase activity fell off rapidly, within $24 \mathrm{hrs}$., and returned to normal within 3 weeks, whereas the erythrocyte esterase activity decreased gradually and remained low for at least 4 weeks after dosing.

Peak plasma levels of famphur, varying between 1 and 16 p.p.m., were attained within 5-33 hrs., after a dose of $30 \mathrm{mg}$ famphur per $\mathrm{kg}$ body weight ( 7 reindeer). The plasma levels declined to below 0.02 p.p.m. in 72-96 hrs. Famoxon, the oxygen analogue of famphur, was observed for $1-2$ days in plasma at low levels, amounting to about $10 \%$ of the corresponding famphur levels. In erythrocytes practically no residues were found of either compound.

Tissue residue levels were low - except at the injection site. In a series of animals given a dose of $30 \mathrm{mg} / \mathrm{kg}$ body weight and killed at varying times after treatment famphur or famoxon were detectable in liver for 4.5 days and in kidney and skeletal muscle remote from the injection site for 12 days. In muscle tissue from the injection site highly variable residue levels were observed, indicating absorption from the intramuscular depot to be erratic.

The experimental results suggest that no appreciable consumer hazard would arise from a proposed single-dose intramuscular treatment of reindeer with famphur at a dosage not exceeding $30 \mathrm{mg} / \mathrm{kg}$ body weight, provided a minimum interval of 3 weeks is maintained between treatment and slaughter and the muscle tissue around the injection site is discarded.

\section{SAMMANFATTNING}

Elimineringshastigheten av famphur - en fosforparasiticid - hos ren.

Famphur (0,0-dimetyl-0,p-(N,N-dimetylsulfamoyl)-fenylfosfortioat) är en lovande systemisk parasiticid mot renstynget och svalgbromsen. Föreningen gavs (i form av preparatet Warbex) som intramuskulär engångsdos till renar.

Efter en dos av $20 \mathrm{mg}$ famphur per kg kroppsvikt (2 djur) iakttogs en sänkning till ca $50 \%$ av kolinesterasaktiviteten i såväl plasma 
som röda blodkroppar. Plasmaaktiviteten sjönk snabbt (inom $24 \mathrm{t}$ och steg till normal nivå inom 3 veckor, medan erytrocytaktiviteten avtog långsamt och förblev låg under minst 4 veckor.

Efter en dos av famphur av $30 \mathrm{mg} / \mathrm{kg}$ (7 djur) uppnåddes maximala plasmakoncentrationer på 1-16 p.p.m. inom 5-33 t. Inom 72$96 \mathrm{t}$ efter dos avtog halterna till mindre än 0,02 p.p.m. Syreanalogen till famphur, famoxon, uppträdde under 1-2 dagar $i$ plasma $i$ låga halter, uppgående till ca. $10 \%$ av famphurhalterna. I röda blodkroppar påvisades endast obetydliga resthalter av famphur och famoxon.

Hos en serie djur, som avlivades vid olika tider efter en dos av famphur av $30 \mathrm{mg} / \mathrm{kg}$, kunde famphur och famoxon påvisas i levern intill 4,5 dagar och $i$ njurar och skelettmuskulatur (utom injektionsstället) intill 12 dagar efter dos. Resthalterna $i$ muskulatur från injektionsstället varierade oregelbundet, utvisande en ojämn resorption från den intramuskulära depån.

Av resultaten att döma torde en engångsbehandling av ren med famphur i dos av högst $30 \mathrm{mg} / \mathrm{kg}$ (i.m.) icke medföra livsmedelshygieniska risker, förutsatt att minst 3 veckor förflyter mellan behandling och slakt och att köttet kring injektionsstället kasseras.

(Received Ocober 6, 1969). 